\title{
Accidents at Work and Costs Analysis: A Field Study in a Large Italian Company
}

\author{
Massimo BATTAGLIA $^{1 *}$, Marco FREY ${ }^{1}$ and Emilio PASSETTI ${ }^{1}$ \\ ${ }^{1}$ Institute of Management, Scuola Superiore Sant'Anna, Italy \\ Received August 19, 2013 and accepted April 17, 2014 Published online in J-STAGE May 28, 2014
}

\begin{abstract}
Accidents at work are still a heavy burden in social and economic terms, and action to improve health and safety standards at work offers great potential gains not only to employers, but also to individuals and society as a whole. However, companies often are not interested to measure the costs of accidents even if cost information may facilitate preventive occupational health and safety management initiatives. The field study, carried out in a large Italian company, illustrates technical and organisational aspects associated with the implementation of an accident costs analysis tool. The results indicate that the implementation (and the use) of the tool requires a considerable commitment by the company, that accident costs analysis should serve to reinforce the importance of health and safety prevention and that the economic dimension of accidents is substantial. The study also suggests practical ways to facilitate the implementation and the moral acceptance of the accounting technology.
\end{abstract}

Key words: Accident costs, Accidents at work, Social accounting, Occupational health and safety, Italy

\section{Introduction}

Occupational health and safety management is linked with moral, legislative and business aspects. Moral obligations involve the protection of employees' lives and health. Legal reasons relate to the preventative, punitive and compensatory effects of laws that protect workers' safety. A proactive occupational health and safety management increases employee commitment as well as enhancing the internal climate and external reputation. At the same time it reduces employee injury and accident costs ${ }^{1,2}$.

An important topic of occupational health and safety management is the analysis of accident costs. Accident costs analysis is important from societal, workers and company perspectives. At a societal level, in 2004 the European Commission highlighted that accidents at work

*To whom correspondence should be addressed.

E-mail: m.battaglia@sssup.it

(C) National Institute of Occupational Safety and Health give rise to costs of up to around 55 billion euros ${ }^{3)}$. A follow-up study in 2010 demonstrated that around 3.2\% (6.9 million people) of the workforce in the 27 European Union member states had reported an accident at work ${ }^{2}$. The percentage increases to $8.6 \%$ if work-related health problems are also taken into consideration, indicating that around one worker in ten has had an accident and/or a health problem connected to their job. The International Labour Organisation (ILO) demonstrates that countries with a lower number of accidents achieve a higher level of competitiveness. ILO's study shows that the costs of accidents globally amount to around $4 \%$ of the global GDP ${ }^{4}$.

From a worker perspective, an accident leading to an injury generates pain and suffering, negative consequences to his/her family, a possible reduction in physical capacity, and loss of salary ${ }^{1}$. For companies, accident costs are associated with injuries and work-related ill-health and can have negative effects such as production losses and increased insurance premiums ${ }^{1)}$. Many of these costs are difficult to evaluate, especially from an economic perspec- 
tive $^{5)}$. However, usually the work accidents are analysed focusing on root cause analysis without giving particular importance to the economic perspective. In this regard, the literature shows technical (lack of data) and organisational (low political power of health and safety department and of knowledge on the topic) barriers that hinder accurate and effective accident costs analyses ${ }^{6}$. The literature also underlines that the aim of the accident costs analysis is to educate companies, using an economic language, in the importance of investing in proactive activities to increase the effectiveness of occupational health and safety management $^{7,8)}$.

In order to contribute to the literature on work accidents analysis, the paper analyses the implementation of a tool for accidents costs analysis in a large Italian company (hereafter referred to as "Healthy Company") ${ }^{1}$ illustrating the technical and the organisational aspects linked to the accidents costs analysis tool. The paper contributes to the literature by presenting a cost analysis tool that could potentially be used by other companies and by discussing the opportunities and difficulties that a company has to face in its implementation. The paper is structured as follow. Section 2 presents the research method, section 3 the various phases of field study and the conclusions and avenues for future research are provided in the final section.

\section{Research Method}

The research was carried out using interventionist research, and specifically constructive research, aimed at problem solving in a real-life organisational setting, constructing new management tools and/or solutions ${ }^{9,10)}$. Interventionist research is part of a family of case research in accounting and management, and it is aimed at revealing the "theory-in-use" rather than the "espoused theory". It is grounded in action in order to refine, test, illustrate or construct theory ${ }^{10)}$ and the researchers are directly involved in the real-time flow of events, instead of observing at a distance or working with ex post facts.

The research method involves the active engagement with local logic and practice, rather than an exclusively conceptual perspective ${ }^{10,11)}$. A key advantage of interventionist research is the opportunity to collect more suitable and significant data than with more traditional research methods. Practical involvement should lead to theoretical contributions that should qualify the project as scientific research instead of consulting activities (Fig. 1).

A theoretical contribution can be produced in two ways. Firstly, the new construction such as a new tool or mana-

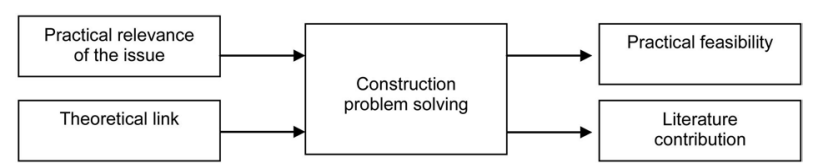

Fig. 1. The logic of interventionist research.

gerial solution may contribute to the design knowledge in the area analysed. In this case, it is necessary to show how it has contributed to a desirable practical solution. For example, the contribution may assume the status of a design rule for practitioners and may provide a starting point for further testing by researchers. Secondly, interventionist research can develop, illustrate, refine and test an existing theoretical knowledge based on the results emerging from the case ${ }^{9,10)}$.

Specifically, constructive research is based on the following phases ${ }^{12)}: 1$ ) to find a practical and relevant problem, which also has research potential; 2) to examine the potential for long-term cooperation with the target organisation; 3) to obtain a general and comprehensive understanding of the topic; 4) to construct a theoretically grounded solution; 5) to implement the solution and test whether it works in practice; 6) to examine the scope of the solution's applicability and, finally, 7) to show the research contribution of the solution. These phases may partly overlap with the preceding or subsequent phases. The third step continues throughout the whole research process, as does the seventh step. The seven steps involved can be also aggregated into three macro-phases ${ }^{13)}$ : the preparatory phase (steps 1 to 3), the fieldwork phase (steps 4 to 5), and the analysis phase (steps 6 and 7).

The next section goes through each of the three macrosteps by providing detailed insights and specific examples. For each of the three macro-sections, specific insight concerning each of the seven specific phases will be provided. By showing how the case study was carried out using constructive research, a detailed analysis of the findings is provided $^{13)}$.

\section{The Preparatory Phase}

\section{Practical and relevant research problem}

The initial idea for this study originated from a discussion with the human resource manager of the "healthy company" in a public meeting on health and safety management in 2010. In the following year, the "healthy company" developed a large program of activities consisting of 15 specific safety-management related projects. 
Table 1. Cost categories and their significance

\begin{tabular}{|c|c|c|}
\hline Categories & Criteria & Significance \\
\hline Internal/external & $\begin{array}{l}\text { The cost is paid by the organization and/or by others } \\
\text { (national insurance system, workers, community). An } \\
\text { internal cost to the firm is a cost which the firm has to } \\
\text { pay, while an external cost is one which is attributable } \\
\text { to the activities of the firm but is paid by others external } \\
\text { to it }\end{array}$ & $\begin{array}{l}\text { This classification can reduce the incentive to invest in } \\
\text { preventive actions by the companies when the portion of } \\
\text { the costs paid by others is higher compared to the total } \\
\text { amount of the cost }\end{array}$ \\
\hline Direct/indirect & $\begin{array}{l}\text { How the cost can be allocated to the accident is the key } \\
\text { criteria of the method. When the cost can be allocated } \\
\text { directly to the accident, it is a direct cost (medical } \\
\text { expenses, wages of the victim, etc.). In other cases, it is } \\
\text { an indirect cost (production losses, damage of corporate } \\
\text { image, etc.) }\end{array}$ & $\begin{array}{l}\text { This classification is important because it can stimulate } \\
\text { employers to search for hidden costs in order to deter- } \\
\text { mine the "true" value of the costs of the accident }\end{array}$ \\
\hline Fixed/variable & $\begin{array}{l}\text { This analyses whether the cost remains constant despite } \\
\text { changes in the incidence and severity of injuries and } \\
\text { illnesses }\end{array}$ & $\begin{array}{l}\text { This classification determines the economic incentive for } \\
\text { an individual decision-maker to take measures to reduce } \\
\text { incidence or severity rates. From an economic perspec- } \\
\text { tive, only the increase in variable costs provides a motive } \\
\text { for the company to reduce its occupational risk }\end{array}$ \\
\hline Economic/non-economic & $\begin{array}{l}\text { This is divided into the costs that can be measured using } \\
\text { a monetary metric or the costs that can be measure using } \\
\text { non-monetary metrics }\end{array}$ & $\begin{array}{l}\text { This classification gives a broad overview of the many } \\
\text { consequences that accidents can generate. It also helps } \\
\text { to discover the external and long-term implications of } \\
\text { accidents }\end{array}$ \\
\hline
\end{tabular}

The overall target of the project was to build up a safety culture based on proactive conduct and preventive actions. Among the 15 projects, one was dedicated to the economic measurement of work accidents.

In this regard, our initial literature review confirmed that the relationship between accidents at work and cost analysis was considered theoretically challenging ${ }^{14,15)}$. No ready-made solutions were available and previous research had prevalently focused on the development of theoretical models with a low level of application within companies ${ }^{5}$. The possibility of developing and testing a cost tool to measure accidents at work was therefore considered as an important opportunity, both by the company and by the research team. Specifically, for the company the project would have enabled to calculate and reveal the costs of accidents that had never been analyzed before.

\section{Examining the potential for long-term co-operation}

The project was designed on a period of 12 months. The time frame of 12 months was considered adequate to carry out the research and to establish positive cooperation between the company and the research team. Gaining and maintaining the commitment of the case organisation is crucial for a successful constructive research study ${ }^{9}$. Another aspect that was verified before starting the project was the values of the participants. If the values of the researcher are in contrast with those of the case organisation, co-operation is unlikely to be effective ${ }^{10,16)}$. In our case, since the topic was considered important both from a company perspective and from an academic perspective, the values of the researcher and the case unit were well aligned. The research team was given a budget by the company to cover travel expenses plus a contribution to the research grant of the junior member. In addition, it was informally agreed that all the data collected could be used, but the company itself wanted to remain anonymous. Finally, it was decided to produce a final report for the company concerning the results achieved.

\section{Obtaining a deep understanding of the topic}

The cost of an accident in the workplace has been defined as "effects on the costs [...] of a company that would not have been borne if the injury/accident had not taken place $^{\text {"1) }}$. Calculating the costs of accidents at work presents difficulties and methodological problems. The first difficulty lies in identifying all the consequences deriving from an accident. Many studies seem to only consider a subset of consequences ${ }^{17,18)}$. Identifying the consequences of work accidents is very difficult since the causal relationship between accident and consequences is not always clear and not all consequences incur at the same time or place. Others barriers include the limited time and 
Table 2. Comparison of the different tools

\begin{tabular}{|c|c|c|c|c|}
\hline & $\begin{array}{c}\text { Accident Consequence } \\
\text { Tree method } \\
\text { (28) }\end{array}$ & $\begin{array}{c}\text { The Systematic Accident } \\
\text { Costs Analysis }{ }^{6)}\end{array}$ & CERSSO method ${ }^{30)}$ & $\begin{array}{c}\text { The Incident } \\
\text { Cost Calculator }^{31)}\end{array}$ \\
\hline Main characteristics & $\begin{array}{l}\text { - Six overall categories } \\
\text { are used to classify } \\
\text { consequences of work } \\
\text { accidents } \\
\text { - Can be integrated with } \\
\text { other tools for accident } \\
\text { analysis }\end{array}$ & $\begin{array}{l}\text { - Six overall categories of } \\
\text { activities, containing } 30 \\
\text { activity "archetypes", are } \\
\text { used to define the over-all } \\
\text { categories of accident } \\
\text { costs } \\
\text { - Can be integrated with } \\
\text { other tools for accidents } \\
\text { analysis }\end{array}$ & $\begin{array}{l}\text { - Integrates epidemiological, } \\
\text { risk assessment, engineer- } \\
\text { ing, and accountability } \\
\text { issues } \\
\text { - Can be used for (a) risk } \\
\text { assessments in the work- } \\
\text { places (risk factors); (b) } \\
\text { identifying cause-effect } \\
\text { relationships; (c) improving } \\
\text { decision making on OSH } \\
\text { interventions; (d) calcu- } \\
\text { lating direct and indirect } \\
\text { costs and savings; and (e) } \\
\text { calculating the overall cost- } \\
\text { benefit of OSH }\end{array}$ & $\begin{array}{l}\text { - Provides five categories of } \\
\text { accident costs that cover } \\
\text { both actions to be carried } \\
\text { out concurrently with } \\
\text { the accident and after the } \\
\text { accident } \\
\text { - is intended to educate } \\
\text { employers on all the costs } \\
\text { associated with workplace } \\
\text { incidents or injuries }\end{array}$ \\
\hline Strengths & $\begin{array}{l}\text { - Conceptually interesting } \\
\text { because it provides a } \\
\text { detailed analysis of the } \\
\text { consequences } \\
\text { - Flexibility on the specific } \\
\text { characteristics of the } \\
\text { company } \\
\text { - Can be used for both real } \\
\text { time (prevalently) and } \\
\text { ex-post analysis }\end{array}$ & $\begin{array}{l}\text { - Easy to understand the } \\
\text { cost elements used to } \\
\text { measure accident costs } \\
\text { - Flexibility on the spe- } \\
\text { cific characteristics of the } \\
\text { company } \\
\text { - Can be used for both real } \\
\text { time and ex-post analysis } \\
\text { (prevalently) }\end{array}$ & $\begin{array}{l}\text { - Permits a complete analy- } \\
\text { sis of the accidents and of } \\
\text { health and safety issues } \\
\text { - Widely used in companies }\end{array}$ & $\begin{array}{l}\text { - Adaptable to the charac- } \\
\text { teristics of the company/ } \\
\text { sector } \\
\text { - Accurate analysis of ac- } \\
\text { cident consequences } \\
\text { - Promoted by the Ministry } \\
\text { of Manpower Singapore, } \\
\text { its methodology has been } \\
\text { replicated by several pub- } \\
\text { lic institutions worldwide } \\
\text { (Canada, Australia) } \\
\text { - Publically available }\end{array}$ \\
\hline Weaknesses & $\begin{array}{l}\text { - Lack of specific defini- } \\
\text { tion of the costs associ- } \\
\text { ated with each of the } \\
\text { specific consequences } \\
\text { - Cost elements may be } \\
\text { difficult for management } \\
\text { to use as they would } \\
\text { require a high number of } \\
\text { definitions and clarifica- } \\
\text { tions before use } \\
\text { - Few documented appli- } \\
\text { cations in practice }\end{array}$ & $\begin{array}{l}\text { - The six categories focus } \\
\text { on the analysis of the } \\
\text { activities to be carried out } \\
\text { after the accidents } \\
\text { - Lack of activities related } \\
\text { to the analysis of the } \\
\text { cause (s) of the accidents } \\
\text { - Few documented applica- } \\
\text { tions in practice }\end{array}$ & $\begin{array}{l}\text { - Complex to implement } \\
\text { cost categories such as } \\
\text { direct and indirect cost is } \\
\text { not completely clear }\end{array}$ & $\begin{array}{l}\text { - The method is intuitive but } \\
\text { lacks clear guidelines for } \\
\text { its application } \\
\text { - Risks being perceived as } \\
\text { a coercive and top-down } \\
\text { approach by the company } \\
\text { if implemented by external } \\
\text { agents }\end{array}$ \\
\hline
\end{tabular}

resources available, the perceived complexity of the task, biases in the accounting system, ethical doubts, as well as the lack of expertise and low status for (or nonexistence of) occupational health and safety departments ${ }^{6}$.

The literature provides an ample spectrum of the methodologies used to classify and measure accident $\operatorname{costs}{ }^{5}$. One distinction is between the external and internal costs. Some examples of internal costs include loss of productivity, and the investigation time spent, while examples of external costs are the victim's medical expenses not compensated through workers' compensation or other employer-paid insurance or the time and resources expended by the victim's household in nursing and recuperation. Another distinction is between direct and indirect costs which highlights that not all costs are visible ${ }^{19,20)}$. The distinction between fixed and variable costs is a third criterion. It shows that many costs vary with the incidence of work accidents and work-related ill-health. Finally, the distinction between tangible and intangible costs refers to the fact that some consequences cannot be expressed in 
Table 3. The starting structure of accidents cost analysis tool

\begin{tabular}{|c|c|c|c|c|}
\hline $\begin{array}{l}\text { A - Cost of } \\
\text { the accident }\end{array}$ & $\begin{array}{l}\text { B - Cost of the accident root } \\
\text { cause analysis }\end{array}$ & $\begin{array}{c}\mathrm{C}-\text { Cost of damages caused } \\
\text { to and/or replacement of } \\
\text { equipment }\end{array}$ & $\begin{array}{l}\mathrm{D}-\text { Cost for resuming } \\
\text { business activities }\end{array}$ & $\begin{array}{l}\text { E - Compensation } \\
\text { and penalties }\end{array}$ \\
\hline Injury first aid & $\begin{array}{l}\text { Incident cause analysis (field } \\
\text { investigations) }\end{array}$ & $\begin{array}{l}\text { Cost of damaged } \\
\text { structure (impairment) }\end{array}$ & Reorganisation of production & $\begin{array}{l}\text { Compensation for } \\
\text { damage caused }\end{array}$ \\
\hline $\begin{array}{l}\text { Transport to } \\
\text { healthcare structures }\end{array}$ & $\begin{array}{l}\text { Completion of incident re- } \\
\text { ports for injury management }\end{array}$ & $\begin{array}{l}\text { Cost of repairs/replacement } \\
\text { of tangible asset (equipment, } \\
\text { machinery, etc.) }\end{array}$ & $\begin{array}{l}\text { Overtime to recover produc- } \\
\text { tion losses }\end{array}$ & Contractual penalties \\
\hline $\begin{array}{l}\text { Cost of materials/ } \\
\text { equipment used to } \\
\text { manage the injury }\end{array}$ & $\begin{array}{l}\text { Completion of other internal } \\
\text { documentation necessary to } \\
\text { manage the injury }\end{array}$ & $\begin{array}{l}\text { Cost of new equipment, } \\
\text { including cleaning and } \\
\text { disposal }\end{array}$ & Time for selecting new staff & $\begin{array}{l}\text { Orders cancelled or } \\
\text { lost (lack of rev- } \\
\text { enues) }\end{array}$ \\
\hline $\begin{array}{l}\text { Period of absence by } \\
\text { the injured worker }\end{array}$ & $\begin{array}{l}\text { Completion of documenta- } \\
\text { tion for public authorities } \\
\text { (documents for INAIL - the } \\
\text { Italian social security organi- } \\
\text { zation, etc.) }\end{array}$ & & $\begin{array}{l}\text { Staff training in order to } \\
\text { resume business after injury }\end{array}$ & $\begin{array}{l}\text { Cost of lawsuits } \\
\text { (legal expenses) }\end{array}$ \\
\hline $\begin{array}{l}\text { Loss of time by } \\
\text { other workers }\end{array}$ & $\begin{array}{l}\text { Meetings with public au- } \\
\text { thorities to analyse incidents }\end{array}$ & & $\begin{array}{l}\text { Cost of staff hired for the } \\
\text { period in which the injured } \\
\text { person is absent from work }\end{array}$ & $\begin{array}{l}\text { Fines/administrative } \\
\text { sanctions }\end{array}$ \\
\hline $\begin{array}{l}\text { Loss of business } \\
\text { due to a halt } \\
\text { in production }\end{array}$ & $\begin{array}{l}\text { Time dedicated to people } \\
\text { involved in internal meetings } \\
\text { relating to the analysis of the } \\
\text { cause of the injury }\end{array}$ & & $\begin{array}{l}\text { Cost of any outsourcing of a } \\
\text { service/activity }\end{array}$ & $\begin{array}{l}\text { Increased insurance } \\
\text { premiums }\end{array}$ \\
\hline $\begin{array}{l}\text { Health cost withheld } \\
\text { for injured and } \\
\text { non-injured staff }\end{array}$ & $\begin{array}{l}\text { Cost of external consultation } \\
\text { to assess injury }\end{array}$ & & & $\begin{array}{l}\text { Absence of return on } \\
\text { capital }\end{array}$ \\
\hline $\begin{array}{l}\text { INAIL excess for } \\
\text { days absent }\end{array}$ & & & & Other (specify) \\
\hline \multicolumn{5}{|l|}{$\begin{array}{l}\text { External communi- } \\
\text { cation concerning } \\
\text { the incident }\end{array}$} \\
\hline Total A & Total B & Total C & Total D & Total E \\
\hline
\end{tabular}

monetary values ${ }^{21)}$, as indicated in Table 1 .

In parallel, several accident cost analysis tools are available in the literature ${ }^{22-26)}$. These tools can be classified into three different approaches ${ }^{1)}$ : insurance-based, activitybased, and labour capacity based.

Insurance-based approaches analyse costs from an insurance perspective and focus on which costs are refunded and those that are not. Insurance costing models are based on worker compensation insurance information that should be available in a company's accounting system ${ }^{27)}$. These methods can have the advantage of data availability but require an in-depth knowledge of insurance issues which is not an easy topic to address ${ }^{15)}$. As such, these studies do not provide a practical method for companies and often involve cost categories that do not give a complete representation of the costs occurred. Their aim is rather to give an insight of the costs of accidents at work and work-related ill-health by calculating the ratio between the different cost categories ${ }^{15}$.

The activity based approach is aimed at developing tools that can be applied by management ${ }^{28)}$. The focus is on measuring health and safety costs to support decision making ${ }^{29)}$. This approach is based upon documenting all the activities (consequences) that the event in question has generated and then evaluating the costs of these activities ${ }^{15}$. Compared to an insurance based-approach, it provides a more tailor-made analysis, thus enhancing the visibility and transparency of the accident costs ${ }^{28)}$.

The labour capacity based approach assesses the consequences of absenteeism rather the economic quantification of work accidents. Several methodologies make up this type of analysis ${ }^{1}$. They range from calculating the costs of absenteeism and lost production, to calculating the costs per uninterrupted working hour ${ }^{31)}$. Of the three classes of 
methods, the labour capacity-based approach has been the least developed in the literature because it mainly focuses on productivity level analysis and not on an investigation of work accidents.

After a series of meetings with the company, the activity-based approach was considered the most suited for identifying all the consequences and the associated costs of accidents and thus for decision making ${ }^{15,28)}$. A detailed analysis of four activity based methods was then made in order to identify which should form the basis for developing the tool (Table 2).

\section{The Fieldwork Phase}

\section{Creating a novel construct}

After the preparatory phase, we established a close cooperation with the company. Six meetings were necessary to define the final tool for accident costs analysis. During the meetings with the human resources manager and health and safety manager, we discussed the macro and micro categories of activities with which to develop the tool, the type of information (monetary and/or non-monetary) to use, the duration of the experimentation, and the number of accidents with which to test the validity and reliability of the tool. Given that none of the tools in Table 2 could be perfectly applied to the case company, it was decided to build an ad-hoc tool. Our tool was designed taken into consideration the «Incident Cost Calculator» with regard the five macro categories of activities and the «Accident Consequence Tree Method», the "Incident Cost Calculator» and the "Systematic Accident Costs Analysis» with regard the identification of the specific consequences of accident within each of the five macro categories of activities. Finally, the «Systematic Accident Costs Analysis» was considered to identify the types of information to analyse.

The tool was based on activity mapping, which provides an accurate picture of the consequences associated with an accident. By identifying these activities, the costs can subsequently be estimated. Activity mapping can facilitate the identification of the costs because the process of data acquisition does not strictly depend on the accounting system, in which data information regarding health and safety are usually mixed and hidden in other cost categories ${ }^{14)}$, such as employee salaries. It was named the "Cost tool for workplace accidents analysis" and consisted of five macro sections (Table 3). Macro section A indicates the costs connected to the accident itself. Macro section B considers the costs associated with the ex-post analysis of the accident. These cover activities required by the law and related administrative procedures, as well as those activities designed to identify and analyse the causes of the accident, particularly when dealing with accidents classified as serious and/or highly serious.

Macro section $\mathrm{C}$ identifies the costs connected to damage caused to company equipment or machinery by the accident. Macro section D covers a series of costs connected to restarting work (if interrupted) and staff training (if necessary/legally required). Finally, macro section E includes costs related to the compensation to be paid by the company to third parties and/or for legal obligations. Within each macro area, a detailed set of items was identified to define as precisely as possible the costs of an accident (Table 3). The tool was structured in a way to guarantee a certain level of flexibility during its use and, at the same time, able to ensure a satisfactory level of coverage of the various cost items.

\section{Implementing and testing the model}

In this phase the cost model was tested and validated empirically with the accidents occurring in 2010 . The accidents occurring during travel to/from the workplace and those with injury periods of under three days were excluded, as they generate few costs which in any case are completely covered by the national insurance system.

The accidents were divided, as suggested by the company, into simple and complex. A simple accident was defined as that resulting only in the absence of the worker involved and without material damage, legal proceedings, etc. Complex accidents covered everything that could not be classified as a simple accident and which caused material damage, legal cases, audits by third parties, etc. The definition of accident categories created some tension between the company and the research team, as we proposed a subdivision on the basis of the level of severity. This would have distinguished between accidents with a low, medium and high level of severity, thus facilitating the identification of a connection between the amount of cost and the level of severity of the accidents.

However, the company did not consider this classification as very useful. It preferred to analyse the costs divided between the costs generated by the absence of the employees (simple accident) and the costs generated by the absence of the employees plus materials, equipment and legal costs (complex accident). This was because the company's aim was to identify the incidence of costs linked to materials and equipment damage and legal actions on the total accident costs. However we underlined that the same results could be achieved also using the level of severity 
Table 4. The final structure of accidents cost analysis tool and the estimated time to undertake activities

\begin{tabular}{|c|c|c|c|c|}
\hline A - Cost of the accident & $\begin{array}{l}\text { B - Cost of the accident } \\
\text { root cause analysis }\end{array}$ & $\begin{array}{l}\mathrm{C} \text { - Cost of damage } \\
\text { caused to and/or } \\
\text { replacement of equipment }\end{array}$ & $\begin{array}{l}\mathrm{D} \text { - Cost of resuming } \\
\text { business activities }\end{array}$ & $\begin{array}{l}\text { E - Compensation } \\
\text { and penalties }\end{array}$ \\
\hline $\begin{array}{l}\text { First aid given to injured } \\
\text { worker by colleagues } \\
{[(\mathrm{A} 1)=1 \mathrm{~h}]}\end{array}$ & $\begin{array}{l}\text { Incident cause analysis by } \\
\text { field investigations } \\
{[(\mathrm{B} 1)=1 \mathrm{~h}]}\end{array}$ & $\begin{array}{l}\text { Cost of damaged equip- } \\
\text { ment (impairment) } \\
{[(\mathrm{C} 1)=\text { not applicable }]}\end{array}$ & $\begin{array}{l}\text { Training of internal staff } \\
\text { replacing injured persons } \\
{[(\mathrm{D} 1)=0.5 \mathrm{~h}]}\end{array}$ & $\begin{array}{l}\text { Compensation for damage } \\
\text { caused (increased insur- } \\
\text { ance) }[(\mathrm{E} 1)=\text { not appli- } \\
\text { cable }]\end{array}$ \\
\hline $\begin{array}{l}\text { Cost of materials/equip- } \\
\text { ment used to manage the } \\
\text { injury [(A2) = not appli- } \\
\text { cable] }\end{array}$ & $\begin{array}{l}\text { Completion of incident } \\
\text { reports for injury manage- } \\
\text { ment }[(\mathrm{B} 2)=1 \mathrm{~h}]\end{array}$ & $\begin{array}{l}\text { Cost of repairs/replacement } \\
\text { of tangible assets (equip- } \\
\text { ment, machinery, etc.) } \\
{[(\mathrm{C} 2)=\text { not applicable }]}\end{array}$ & $\begin{array}{l}\text { Overtime to recover pro- } \\
\text { duction losses }[(\mathrm{D} 2)=4 \mathrm{~h}]\end{array}$ & $\begin{array}{l}\text { Legal expenses for lawsuits } \\
{[(\mathrm{E} 2)=\text { not applicable }]}\end{array}$ \\
\hline $\begin{array}{l}\text { Transport of the injured } \\
\text { person to the healthcare } \\
\text { structures [(A3)=\# } \\
\text { between time at which the } \\
\text { accident took place and } \\
\text { length of shift] }\end{array}$ & \multirow[t]{2}{*}{$\begin{array}{l}\text { Completion of the docu- } \\
\text { mentation needed for: A) } \\
\text { injury management report } \\
\text { B) completion of documen- } \\
\text { tation for public authorities } \\
\text { C) other types of documen- } \\
\text { tation [(B3) }=2.5 \mathrm{~h}]\end{array}$} & $\begin{array}{l}\text { Cost of new equipment, } \\
\text { including cleaning and } \\
\text { disposal }[(\mathrm{C} 3)=\text { not ap- } \\
\text { plicable }]\end{array}$ & $\begin{array}{l}\text { Staff training for resuming } \\
\text { business after injury } \\
{[(\mathrm{D} 3)=4 \mathrm{~h}]}\end{array}$ & $\begin{array}{l}\text { Fines/administrative } \\
\text { sanctions }[(E 3)=\text { not ap- } \\
\text { plicable }]\end{array}$ \\
\hline $\begin{array}{l}\text { Period of absence by the } \\
\text { injured worker on the day } \\
\text { of the injury }[(A 4)=4 \mathrm{~h}]\end{array}$ & & & & $\begin{array}{l}\text { Increased INAIL insur- } \\
\text { ance premiums }[(\mathrm{E} 4)=\text { not } \\
\text { applicable }]\end{array}$ \\
\hline $\begin{array}{l}\text { Interruption of activities by } \\
\text { other workers due to the } \\
\text { incident }[(\mathrm{A} 5)=1.5 \mathrm{~h}]\end{array}$ & $\begin{array}{l}\text { Meetings with public } \\
\text { authorities to analyse } \\
\text { incidents (specify whether } \\
\text { or not the meetings involve } \\
\text { the Supervisory Body) } \\
{[(\mathrm{B} 4)=1.5 \mathrm{~h}]}\end{array}$ & & & \\
\hline $\begin{array}{l}\text { INAIL excess, specifying } \\
\text { whether they are: - first } \\
3 \text { days of absence; - 20th } \\
\text { to 90th day of absence - } \\
\text { beyond the 90th day of } \\
\text { absence [(A6) = not ap- } \\
\text { plicable] }\end{array}$ & $\begin{array}{l}\text { Time dedicated by staff } \\
\text { involved for internal meet- } \\
\text { ings relating to the analysis } \\
\text { of the cause of the injury } \\
{[(\mathrm{B} 5)=1.5 \mathrm{~h}]}\end{array}$ & & & \\
\hline Total A & Total B & Total C & Total D & Total E \\
\hline
\end{tabular}

as criteria for the accident assessment, and the level of severity would lead to better analyses the influence of the length of the accidents on the total costs. Despite this, the company decided to adopt the simplex versus complex criteria.

Based on these premises, the model was applied following ex-post logic, meaning that the calculation of costs was carried out after the accident occurred. Data collection was carried out by the company's Health and Safety office, in collaboration with the Human Resources office (who provided data on average salaries of staff involved in the accidents), and with the Accounting offices (who provided data on invoices and costs of goods and services purchased following the accident). The sections of the cost model were analysed in terms of the time needed to undertake each activity (if necessary) and the relative hourly rates. These two units of measurement (time and hourly rate) together determined the total cost for a simple accident. For complex accidents, repair and maintenance costs and material damage costs were also considered.

The tool was initially tested on a sample of 110 accidents, representing $47 \%$ of accidents that took place in 2010. The research team did not participate directly in the data acquisition process. In this phase, a key problem was the lack of data in the accounting system especially concerning the time dedicated to the analysis of each accident. However, cost centres aggregated accident costs without making any distinctions, thus they were not able to supply detailed information, and a manual adjustment was necessary to identify the value of some items by the accounting 
staff that required overtime.

To resolve some of the problems regarding the lack of time data, an accident report was used. An accident report includes information such as the type of accident and injury occurred, the causes of the accident, the witnesses present, and the job title of the employee. However, the accident report did not provide data on the time required to undertake activities related to managing the activities that follow the occurrence of the accident, in particular concerning the items in macro-section B. As such, a series of interviews with the employees who applied first aid to the injured people and with employees who undertook the administrative procedures were carried out. These interviews enabled the time required to carry out the activities (Table 4) to be estimated and, thus to estimate the related costs.

After an analysis of the first 30 accidents, a check was made by the research team to verify the accuracy of the data and the mood of the staff involved. During this check we asked the company to illustrate each of the 30 accidents regarding the activities analysed and the relative costs. This check was important in order to reassure staff and to overcome some problems. For example, at the beginning, the human resources staff and the accounting staff were unable to fully understand the meaning of some of the items in the tool, and the health and safety staff had some ethical barriers to measuring the accidents in monetary terms. Therefore it was necessary to better explain the meaning of each item and also to guarantee that the aim of the monetary measurement was to reinforce the importance of health and safety management within the company. We provided a series of practical tips on how to resolve some issues (for example how to calculate item A3 and $\mathrm{B} 5$ or to check the value for A6) however company staff carried out the actual data acquisition process. Our role in this phase was to verify that company staffs were able to understand and to acquire all the necessary data for the analysis, by stimulating the learning process and operating autonomously.

The tool was refined after the analysis of the first 110 accidents. Some activities were cut or combined with others, while for others meanings were clarified to prevent possible misunderstandings during the compilation. The refinement was made in collaboration with the health and safety manager and enabled us to define a more accurate tool. The number of items was dropped from 33 to 22 (Table $3)$. The changes particularly involved sections A and B, which were the sections linked with first accident analyses, and section $\mathrm{D}$ which was associated with resuming busi- ness activities. From a methodological point of view, the refinement of the initial tool, following its first application in the field, is considered as a physiological aspect which increases the quality of the work carried out ${ }^{10)}$.

The analysis of the 110 accidents (102 were simple accidents and 8 were complex accidents ${ }^{2}$ ) provided data on the average daily injury cost of a simple accident and the average daily injury cost of a complex accident (average daily injury cost is the average cost per day of injury absence). The average daily injury cost of a simple accident and the average daily injury cost of a complex accident were then used to calculate the cost of the remaining 126 accidents (both simple and complex accidents) in order to estimate the total costs for 2010. After some comparisons between the characteristics of the first and second groups of accidents in terms of average length of injuries, cause and types of accidents, and types of employees involved, the health and safety manager opted to use the average cost of the first group and not to calculate the costs of the other 126 accidents. This decision was motivated by the time required to carry out the analysis. Indeed, the analysis of the first 110 accidents required extra work by all the staff involved in the project due to the more extensive investigation required to analyse each accident. Given the experimental nature of the project, the results of the first group of accidents were considered adequate to evaluate the appropriateness of the tool in providing the economic value of accidents.

Tables 4 and 5 show the time dedicated to the activities of an accident and the total cost for the simple and the complex accidents, respectively. With reference to the data presented, the following should be underlined:

- data related to "average accident cost", "average daily injury cost" and "average length of injury" presented in the total column were calculated as a weighted average in relation to the number of simple and complex accidents;

- data related to "average accident cost" and "average daily injury cost" (Total, Simple and Complex) do not include the Italian workers' compensation authority (INAIL) premiums (neither category A6 nor E3). Due to the numerous variables to be considered in this calculation, the company was unable to calculate the relative cost, either for individual accidents or at a global level ${ }^{3}$;

- On average, the total time dedicated to an accident is $22.5 \mathrm{~h}$; specifically, $18.5 \mathrm{~h}$ and $26.5 \mathrm{~h}$ for simple and complex accidents respectively. The typology of accidents occurring to employees was quite similar and mainly caused by shocks, falls, slips, stumbles and cuts.

Moreover, the macro section B (root cause analysis) re- 
Table 5. Categories and costs of the accidents

\begin{tabular}{lccc}
\hline & Total & Simple & Complex \\
\hline Total accident costs & $€ 1,591,148$ & $€ 1,338,450$ & $€ 251,698$ \\
Total number of accidents & 245 & 224 & 21 \\
Total days of absence for accidents & 7,024 & 6,230 & 794 \\
Average accident cost & $€ 6,494$ & $€ 5,980$ & $€ 11,986$ \\
Average daily injury cost & $€ 266.3$ & $€ 215.00$ & $€ 317.00$ \\
Average length of injury (days) & 28.7 & 27.8 & 37.8 \\
\hline
\end{tabular}

Table 6. Percentages of incidence of macro cost categories on total cost

\begin{tabular}{lcc}
\hline & \multicolumn{2}{c}{ Total } \\
\cline { 2 - 3 } & Simple (\%) & Complex (\%) \\
\hline A - Cost of the accident & 71.0 & 42.9 \\
B - Cost of the accident root cause analysis & 24.8 & 31.1 \\
C - Cost of damage caused to and/or replacement of equipment & 0.0 & 16.3 \\
D - Cost of resuming business activities & 4.2 & 9.7 \\
E - Compensation and penalties & 0.0 & 0.0 \\
\hline
\end{tabular}

ports quite low data with regard to the total time dedicated to an accident because the company, and in particular the health and safety staff, already know why the accidents had occurred. The company divided the root cause analysis into two main types: 1) inefficiency of the management system, 2) external events (such as the weather conditions or blocks and holes in the road) and unpredictable causes. The second type accounted for most cases.

Regarding the inefficiency of the management system, the root cause analysis was more accurate and focused on investigating roles, responsibilities and internal procedures involved, to acquire more information in order to prevent similar accidents in the future. In the case of external events, the root cause analysis was less investigated because the company cannot directly manage or remove the cause of these accidents. In these cases, the aim was to acquire new information to better inform the employee of what they should do during their work or to acquire more advanced protective equipment.

The total costs for all the 236 accidents (i.e. $236 \mathrm{em}$ ployees), mainly regarding operational staff, were almost than $€ 1.6$ million in the year ${ }^{4}$. The average cost of a complex accident double that of a simple accident (Table 5) because complex accidents included a series of post-accident activities that simple accidents did not present. The difference between the average daily cost of the simple accident compared to the complex one is less significant $(+47 \%)$. This minor gap is caused by the difference in the average length of injury time between the two classes of accident (average $+10 \mathrm{~d}$ ). In the case of the complex accident, the fixed costs are divided over a long time period and thus their impact on total cost is less.

The data in Table 6 highlight that the most relevant cost categories for simple accidents were the cost of the

\footnotetext{
${ }^{1}$ It is a large, multi-utility company, operating in the water, gas supply and environmental hygiene sector. The company is listed on the Italian stock market, and the majority of shares are held by public authorities. It is certified OHSAS 14001, Emas and OHSAS-18001.

${ }^{2}$ Overall, complex accidents had an incidence of $8.5 \%$ of the total number of accidents.

${ }^{3}$ In compliance with the law, the company pays, for each employee, an annual insurance premium to INAIL, whose value consists of two components: a fixed share and a variable one. The variable share (delta) shifts according to a set of parameters concerning the health and safety performance of the company (such as: number of injury days in the previous year; variation over time in the frequency and severity of accidents; their value in comparison to the sector average; presence or otherwise of a safety certification, such as OHSAS-18001, etc.). This delta is represented by item E4 in Table 4. In addition, for each accident occurring, a further cost has to be considered by the company. Its value (item A6 in Table 6) varies on the basis of the duration of each accident (e.g. the first three days of injury time are completely covered by the company and its daily value depends on the value of the total premium paid. This variability made the ex-post quantification for each accident extremely difficult, hence the decision to eliminate this cost from the calculation for each accident.

${ }^{4}$ The unit cost per full time equivalent is around $246.15 €$. The total costs of accident were around $1.5 \%$ of the net income of the year. At the sector level the cost data were not available because the INAIL do not calculate this kind of information.
} 
accident and the cost of the accident root cause analysis. These categories of costs had a respective weight of $71 \%$ and $24.8 \%$ on total costs, while for complex accidents this stood at $42.9 \%$ and $31.1 \%$. For complex accidents, the cost for damage and for replacement of equipment was significant, with a value of $16.3 \%$. Compensations and sanctions did not have any incidence on the total cost of the accident. In both typologies of accident they had a weight of $0 \%$. This is due to the absence of highly serious accidents and the subsequent lack of legal proceedings and related sanctions.

The difference between the two categories of accidents is caused by their characteristics. Simple accidents had a low percentage of incidence in macro-section B, as they only required standard post-accident activities mostly related to items B2 and B3, but a high percentage of incidence in macro-section A. Complex accidents had a more homogeneous distribution of costs among the various sections, given that they involved damage to equipment and require more complex post-accident activities. Finally, considering the individual items, those registering the highest overall monetary value were $\mathrm{A} 1$ and $\mathrm{A} 3$ (covering direct costs for the employee), followed by B2, B3 and A2.

\section{Analysis Phase}

\section{Analysing the scope of the solution's applicability}

In the last two phases of the constructive work, the idea is that the researchers involved in the project should become detached from the empirical details and consider the wider implications, i.e. the external validity of the research. The sixth step involves discussing those aspects that could facilitate the transfer of the construct to others or to consider implementation problems that are also likely to emerge in other organisations ${ }^{13)}$.

In this regard, the following observations highlight a series of practical suggestions, emerging during the 12 months of the project which could be used for the future implementation of the tool in other organisations. Firstly, the experience of the "healthy company" highlighted the importance of using the tool both in a concomitant and an ex-post way. The concomitant use should be carried out in parallel with the occurrence of the accident to ensure the correct identification of the time needed to undertake those activities strictly related to the immediate management of the accident. The use of the tool should also be integrated with the technical analysis of its causes in order to joint monetary and qualitative analysis. On the other hand, the ex-post analysis of the tool should focus on sections B, C,
D, E. It is thus important to identify the staff which provide the information on the accident and ensure that they are able to supply the specific data.

Secondly, in order to have common knowledge and a complete representation of all the activities related to an accident, an official flow-chart related to the accident analysis should be defined and given to all the staff involved in order to facilitate a complete analysis of the costs. For example, in our case the accounting department only had limited knowledge of the consequences of an accident. Thirdly, it is important to create strong collaboration and commitment between the various types of staff (health and safety, human resources, accounting and operations areas) involved in the measurement and analysis process. Concerning our field study, the development of the tool was part of a larger project dedicated to build a strong culture of safety. As such, the tool had the endorsement of the top management who facilitated the course of the projects, and staffs were available to ensure the success of the project.

During the field study, we helped create a common language on the topic by carrying out meetings with the various departments and supporting their learning process by giving (positive or negative) feedback on their activities. Thus, fully exploiting an accident costs analysis tool entails training all the staff involved in collecting, transmitting and analysing data. Training should increase staff skills and ensure, at the same time, that the tool becomes accepted and shared across all the departments in order to guarantee its correct use. Specifically, health and safety office should be trained and involved in collecting data and information on accident causes, while accounting department should record all cost categories linked with damage costs and the replacement of the equipment. Finally, human resource department should be able to provide correct information on the time needed for post-accident administrative management and the salaries of the staff involved in the accident itself.

Fourthly, in order to facilitate accident data acquisition, accounting systems could be structured in order to facilitate the acquisition of accidents data. Often, cost centres aggregate accident costs indistinctly, thus they are not able to supply detailed information ${ }^{8}$. This may help to explain why many companies do not measure the economic value of accidents at work, in addition to the moral and ethical obstacles. A possible solution for facilitating data acquisition and analysis could be to insert accident costs analysis into budgeting and management control. In our case, the human resource staffs were not completely convinced by such a solution. For them the goal was to reduce the 
number of accidents to as few as possible and thus all the activities should be aimed at promoting a culture of safety within the company alongside proactive health and safety management practices.

Similarly, the health and safety manager considered that the primary goal was to develop effective health and safety management practices; however he was open to the idea of inserting accident costs into the budgeting and management control system. For him, the value added was being able to show in financial terms the value created by health and safety management (as a consequence of fewer accidents at work) and also the opportunity to have more precise costs information in order to guide future investment decisions. Concerning the inclusion of health and safety within the performance evaluation and incentive system, the company had adopted a balanced scorecard in which, some targets concerning health and safety, such as obtaining SA 8000 certification and the diffusion of OHSAS 18001 for all the companies in the group, were included within the learning and growth perspective.

\section{Showing the (theoretical) contributions}

In this section, we show how we believe our study has made a contribution to the field of work accidents analysis. Firstly, in terms of costs, the literature indicates that accident costs tend to grow in proportion to accident severity. Although the accidents were classified as simple or complex, the results seem to confirm the tendency of a progressive increase in costs as the severity (and managerial complexity) of the accident increases ${ }^{1)}$. When the accident did not require more specific managerial activities in the ex-post phase, such as simple accidents, the costs were greater. Another aspect is the attitude of employees and staff towards the measurement of accidents at work. During the project, staff in the human resources and health and safety departments acquired greater awareness on the use of the cost model. However there were some moments of conflict with our team since the aims of the project were not initially fully shared and understood. It is thus important to immediately build a relationship of trust between the company and the research team and to provide initial training and information ${ }^{16)}$.

Secondly, this kind of tool can only be implemented effectively if it is considered as an educational tool for developing a culture of safety and not as an accounting tool for monitoring and controlling company accident expenses. The experiences showed that calculating occupational accident costs can clearly illustrate the value created by the occupational health and safety department by preventing accidents ${ }^{32}$. However this type of measurement must be linked with the implementation of other managerial tools, such as health and safety certifications (OHSAS 18001 or SA 8000), cost/benefit analysis and leading safety indicators ${ }^{33)}$ in order to better evaluate and plan past and future health and safety performances.

This implementation and use of different managerial tools could increase the relevance of health and safety issues within a company in a similar way to other areas, such as production or commercial functions. The tools should therefore have the capacity to build skills within the company and to provide support in achieving health and safety targets in an ethical, effective and efficient way $^{34,35)}$.

\section{Conclusions}

Occupational health and safety management is a problematic field of analysis, which is linked with moral, ethical, legislative and economic aspects. In this paper, the focus has been on the costs analysis of accidents, which is important to increase information and awareness on the complexity of health and safety issues.

Our study highlighted both the technical and organisational aspects to consider when a company decides to measure accident costs. From a technical perspective, the accidents cost analysis tool should be linked and integrated with ordinary management activities and in particular with accident analysis reports, accounting systems and management control in order to facilitate data acquisition and analysis. From an organisational perspective, the implementation (and the use) of an accidents costs analysis tool requires comprehensive planning in order to promote the sharing and acceptance of the tool within the organisation. Therefore, all attempts to economically measure health and safety issues should be carefully planned and gradually introduced into company mechanisms. Consequently, accident costs analysis does not contrast with the achievement of zero accidents but rather serves as a complementary technology to be part of occupational health and safety management practices and safety culture.

We encountered a number of limitations, such as the use of the differentiation between simple and complex as the only criterion for classifying accidents and the inability to calculate the INAIL premium to obtain the full costs of the accidents. Moreover, as indicated in the literature ${ }^{36)}$, the results cannot be easily transferred to other situations but require further investigations. A third limitation concerns the structure of the model itself, or rather the cost items 
inserted. These were identified through an agreement with the company, and some were refined during the analysis. It is possible to insert (or cut) other items or to further subdivides some existing items into more specific ones. This would be possible if company operates in a different sector, or if company carries out different investigations, and also if the normative structure related to occupational health and safety in any given country requires different administrative burdens and activities. Despite these differences, the process that led to the cost model definition and implementation could be replicated in other contexts.

An area for future research would be to investigate costs versus benefits analysis as a proactive occupational health and safety management practice. Another avenue for further research could be to identify and measure the social costs of accidents. Finally it would be useful to investigate how accident cost analysis contributes to organisational learning and change.

\section{Acknowledgement}

We are very grateful to the editor in chief and two anonymous referees for their constructive comments during the reviewing process.

\section{References}

1) European Commission (2011) Socio-economics of cost of accident at work and work-related ill health. http:// ec.europa.eu/social/publications. Accessed March 9, 2013.

2) Eurostat (2010) Health and safety at work in Europe (1999-2007). A statistical portrait. http://epp.eurostat. ec.europa.eu/portal/page/portal/health/health_safety_work. Accessed March 10, 2013.

3) Eurostat (2004) Statistical analysis of socio-economic costs of accidents at work in the European Union http:// www.healthy-workplaces.eu/data/links/osh_link.2005-0118.9169779282. Accessed February 2, 2013.

4) International Labour Organization (2006) Occupational safety and health: synergy between security and productivity. http://www.ilo.org/global/publications/langen/index.htm. Accessed February 2, 2013.

5) Jallon R, Imbeau D, de Marcellis-Warin N (2011) Development of an indirect-cost calculation model suitable for workplace use. J Safety Res 42, 149-64. [Medline] [CrossRef]

6) Rikhardsson PM, Impgaard M (2004) Corporate cost of occupational accidents: an activity-based analysis. Accid Anal Prev 36, 173-82. [Medline] [CrossRef]

7) Weil D (2001) Valuing the economic consequences of work injury and illness: a comparison of methods and findings. Am J Ind Med 40, 418-37. [Medline] [CrossRef]
8) Biddle E, Ray T, Owusu-Edusei K Jr, Camm T (2005) Synthesis and recommendations of the economic evaluation of OHS interventions at the company level conference. J Safety Res 36, 261-7. [Medline] [CrossRef]

9) Lukka K (2005) Approaches to case research in management accounting: The nature of empirical intervention and theory linkage. In: Accounting in Scandinavia - The Northern Lights, Jönsson A and Mouritsen J (Eds.), 375-399, Liber \& Copenhagen Business School Press, Malmö.

10) Jönsson S, Lukka K (2006) There and back again: doing interventionist research in management accounting. In: Handbook of Management Accounting Research, Chapman CS, Hopwood AG and Shields MD (Eds.), 1, 373-397, Elsevier, Amsterdam.

11) Daltuva JA, King KR, Williams MK, Robins TG (2009) Building a strong foundation for occupational health and safety: action research in the workplace. Am J Ind Med 52, 614-24. [Medline] [CrossRef]

12) Kasanen E, Lukka K, Siitonen A (1993) The constructive approach in management accounting research. J Manage Acc Res 5, 243-64.

13) Labro E, Tuomela TS (2003) On bringing more action in management accounting research: process consideration based on two constructive case studies. Eur Account Rev 12, 409-42. [CrossRef]

14) Rikhardsson PM (2004) Accounting for the cost of occupational accidents. Corp Soc Resp Environ Manag 11, 63-70. [CrossRef]

15) Rikhardsson PM (2006) Accounting for health and safety costs. Review and comparison of selected methods. In: Sustainability accounting and reporting, Schaltegger S, Bennett M and Burritt R (Eds.), 129-151, Springer, Amsterdam.

16) Koningsveld EA (2005) Participation for understanding: an interactive method. J Safety Res 36, 231-6. [Medline] [CrossRef]

17) Tompa E, Dolinschi R, de Oliveira C (2006) Practice and potential of economic evaluation of workplace-based interventions for occupational health and safety. J Occup Rehabil 16, 375-400. [Medline]

18) Tompa E, Dolinschi R, de Oliveira C, Irvin E (2009) A systematic review of occupational health and safety interventions with economic analyses. J Occup Environ Med 51, 1004-23. [Medline] [CrossRef]

19) Huang YH, Leamon TB, Courtney TK, Chen PY, DeArmond S (2007) Corporate financial decision-makers' perceptions of workplace safety. Accid Anal Prev 39, 767-75. [Medline] [CrossRef]

20) Huang YH, Leamon TB, Courtney TK, Chen PY, DeArmond S (2011) A comparison of workplace safety perceptions among financial decision-makers of mediumvs. large-size companies. Accid Anal Prev 43, 1-10. [Medline] [CrossRef]

21) Freeman K, LaFleur BJ, Booth J, Doyle BJ, Pugh WM 
(2001) An actuarial method for estimating the long-term, incidence-based costs of navy civilian occupational injuries and illnesses. J Safety Res 32, 289-97. [CrossRef]

22) Koehler DA (2001) Developments in health and safety accounting at Baxter international. Eco-Manage Audit 8, 229-39. [CrossRef]

23) Gavious A, Mizrahi S, Shani Y, Minchuk Y (2009) The costs of industrial accidents for the organization: developing methods and tools for evaluation and costbenefit analysis of investment in safety. J Loss Prev Process 22, 434-8. [CrossRef]

24) Reville RT, Bhattacharya J, Sager Weinstein LR (2001) New methods and data sources for measuring economic consequences of workplace injuries. Am J Ind Med 40, 452-63. [Medline] [CrossRef]

25) Sun L, Paez O, Lee D, Salem S, Daraiseh N (2006) Estimating the uninsured costs of work-related accidents, part I: a systematic review. Theor Issues Ergon Sci 7, 227-45. [CrossRef]

26) Paez O, Uahinui T, Genaidy A, Karwowski W, Sun L, Daraiseh N (2006) Estimating the uninsured costs of workrelated accidents, part II: an incidence-based model. Theor Issues Ergon Sci 7, 247-60. [CrossRef]

27) Oxenburgh M, Marlow P (2005) The productivity assessment tool: computer-based cost benefit analysis model for the economic assessment of occupational health and safety interventions in the workplace. J Safety Res 36, 209-14. [Medline] [CrossRef]

28) Aaltonen M, Uusi-Rauva E, Saari J, Antti-Poika M, Räsänen T, Vinni K (1996) The accident consequence tree and its application by real-time data collection in the Finnish furniture industry. Saf Sci 23, 11-26. [CrossRef]

29) Grant KA, Garland JG, Joachim TC, Wallen A, Vital $\mathrm{T}$ (2003) Achieving health, safety, and performance improvements through enhanced cost visibility and workplace partnerships. AIHA J (Fairfax, Va) 64, 660-7. [Medline] [CrossRef]

30) Amador-Rodezno R (2005) An overview to CERSSO's self evaluation of the cost-benefit on the investment in occupational safety and health in the textile factories: “a step by step methodology”. J Safety Res 36, 215-29. [Medline] [CrossRef]

31) Frey M, Battaglia M, Passetti E (2014) Investire in sicurezza nel settore dell'igiene urbana, Franco Angeli, Milan.

32) Lahiri S, Gold J, Levenstein C (2005) Net-cost model for workplace interventions. J Safety Res 36, 241-55. [Medline] [CrossRef]

33) Øien K, Utne IB, Herrera IA (2011) Building safety indicators: part 1-theoretical foundation. Saf Sci 49, 148-61. [CrossRef]

34) Granerud RL, Rocha RS (2011) Organisational learning and continuous improvement of health and safety in certified manufacturers. Saf Sci 49, 1030-9. [CrossRef]

35) Holmgren Caicedo M, MÅrtensson M (2010) Extensions and intensions of management control-The inclusion of health. Crit Perspect Account 21, 655-68. [CrossRef]

36) George AL, Bennett A (2005) Case studies and theory development in the social sciences, MIT Press, London. 